\title{
Review
}

Drug/Regimen

Diabetes Metab J 2020;44:785-801

https://doi.org/10.4093/dmj.2020.0179

pISSN 2233-6079 • eISSN 2233-6087

DIAB ET\&S \& M ETABOLISM JOURNAL

\section{Evaluating the Evidence behind the Novel Strategy of Early Combination from Vision to Implementation}

\author{
Päivi Maria Paldánius \\ Research Program for Clinical and Molecular Metabolism, Helsinki University, Helsinki, Finland
}

\begin{abstract}
Type 2 diabetes mellitus (T2DM) is a complex and progressive chronic disease characterised by elevating hyperglycaemia and associated need to gradually intensify therapy in order to achieve and maintain glycaemic control. Treating hyperglycaemia with sequential therapy is proposed to allow holistic assessment of the efficacy and risk-to-benefit ratio of each added component. However, there is an array of evidence supporting the scientific rationale for using synergistic, earlier, modern drug combinations to achieve glycaemic goals, delay the deterioration of glycaemic control, and, therefore, potentially preserve or slow down the declining $\beta$-cell function. Additionally, implementation of early combination(s) may lead to opportunities to combat clinical inertia and other hurdles to optimised disease management outcomes. This review aims to discuss the latest empirical evidence for long-term clinical benefits of this novel strategy of early combination in people with newly diagnosed T2DM versus the current widely-implemented treatment paradigm, which focuses on control of hyperglycaemia using lifestyle interventions followed by sequentially intensified (mostly metformin-based) monotherapy. The recent reported Vildagliptin Efficacy in combination with metfoRmin For earlY treatment of T2DM (VERIFY) study results have provided significant new evidence confirming long-term glycaemic durability and tolerability of a specific early combination in the management of newly diagnosed, treatment-naïve patients worldwide. These results have also contributed to changes in clinical treatment guidelines and standards of care while clinical implementation and individualised treatment decisions based on VERIFY results might face barriers beyond the existing scientific evidence.
\end{abstract}

Keywords: Chronic disease; Diabetes mellitus, type 2; Drug combinations; Early combination strategy; Metformin; Standards of care; Treatment outcome

\section{THE CLINICAL NEED FOR MORE OPTIMISED STRATEGIES AND OUTCOMES}

The high prevalence of type 2 diabetes mellitus (T2DM) is global in nature and continues to increase dramatically, particularly in low- and middle-income countries [1]. Present estimates indicate that approximately 463 million people worldwide have diabetes and that number is expected to increase to a staggering digit of 700 million by 2045 [1]. Prevalence, incidence and heterogeneity of the disease itself among those diagnosed, and progression of the underlying complications vary greatly by geographical location and ethnic groups due to dif- ferences in genetic predisposition, cultural factors, socioeconomic differences, and lifestyle factors such as dietary habits and physical activity [2-5]. Most individuals with diabetes are classified as having T2DM [1] but present with their own unique combination of insulin resistance and impaired insulin secretion, i.e., $\beta$-cell failure [6], while the relative contribution of these two components varies greatly from patient to patient and over time [5,6]. Additionally, the rate of disease progression varies between individuals and cannot be predicted accurately at the time of diagnosis. Even if multiple clinical, laboratory, and genetic markers have been reported to be associated with faster progression after diagnosis [7], it is not possible to ac-
Corresponding author: Päivi Maria Paldánius

(iD) https://orcid.org/0000-0001-5997-4879

Research Program for Clinical and Molecular Metabolism (CAMM), Helsinki University, Biomedicum 1, PO Box 63, FIN-00014, Helsinki, Finland

E-mail:ppaldanius@gmail.com
This is an Open Access article distributed under the terms of the Creative Commons Attribution Non-Commercial License (https://creativecommons.org/licenses/by-nc/4.0/) which permits unrestricted non-commercial use, distribution, and reproduction in any medium, provided the original work is properly cited. 
count for the effect of additional behavioural patterns affecting compliance with, and thereby impact of the dietary and exercise regimens; important predictors for disease progression [7].

The aim of this review is to discuss the advancement in the recent scientific and clinical evidence regarding (1) the established knowledge base regarding the unmet clinical needs and the factors contributing to lack of optimised outcomes; (2) the key learnings from the Vildagliptin Efficacy in combination with metfoRmin For earlY treatment of T2DM (VERIFY) study exploring the long-term benefits of a novel strategy of early combination; and (3) yet to be explored future aspects of more optimised clinical management of individuals newly diagnosed with T2DM (Fig. 1).

\section{TARGETING TO HALT THE PROGRESSION OF DISEASE}

Pathogenesis of T2DM is complex, and stems from multiple metabolic imbalances, abnormalities and defects affecting multiple organ systems $[8,9]$. Therefore, addressing these drivers of progressive disease by initiating pharmacological monotherapy, as is suggested by most treatment algorithms, may not be sufficient. Therefore, early initiation of combination therapy has been proposed by many as a more holistic approach to delay the deterioration of glycaemic control with possible favourable effect on preservation of $\beta$-cell function early on in the disease [10]. Traditionally, recommendations and treatment guidelines have focused on achieving and maintaining glycosylated hemoglobin (HbA1c) targets, while there has been a growing interest in assessing other glycaemic parameters as indicators of response, namely glycaemic fluctuation over 24 hours, including fasting and postprandial glucose values, as well as time spent in extreme hypoglycaemia and hyperglycaemia [11]. In addition to the potential contribution of glycaemic variability as a predictor of outcomes and progression of diabetic complications [12], minimising glucose variability through appropriate selection of components of drug therapy could lead to superior, individualised disease management, and provide better quality of life for patients with diabetes $[11,13]$. However, regardless of the parameters used to determine whether adequate glycaemic control is being achieved and maintained, we should aim to introduce a favourable, disease-modifying effect and/or critically assess the ability of the chosen regimen to halt the progression of the disease and/or its underlying complications.
A) Unmet clinical needs (established evidence)

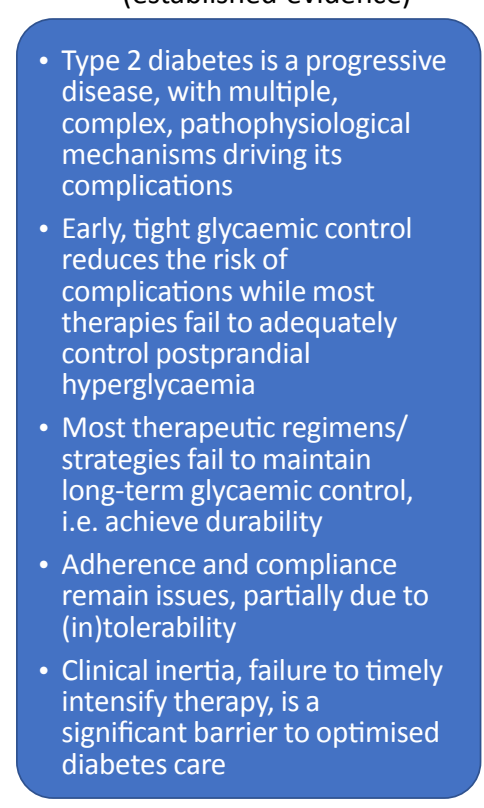

B) Key learnings from the VERIFY study

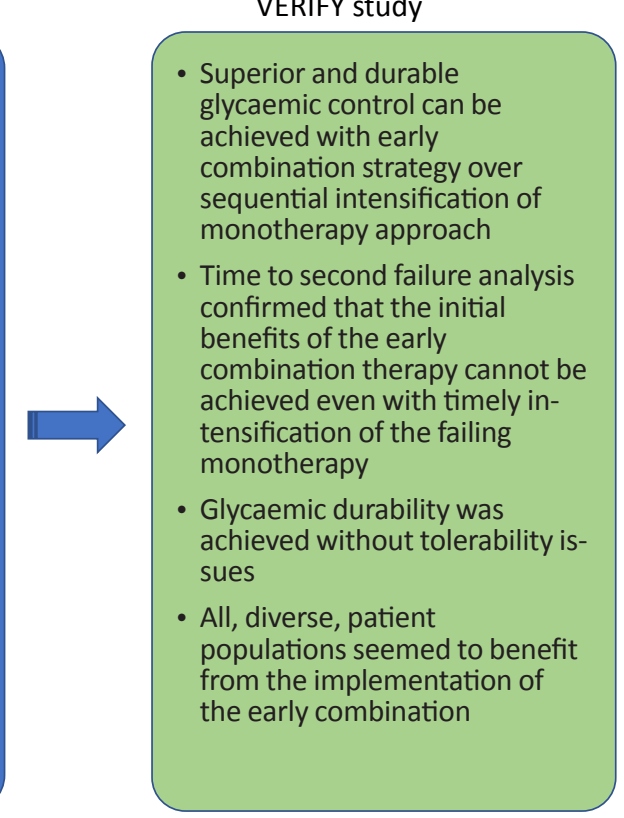

C) What remains to be explored in the future

- Role of metformin as the foundation of care, even in combination with other drugs

- Impact of early combination on disease progression and $\beta$-cell function over time?

- Impact of early detection and conceptual change in disease management paradigm on 'softer' outcomes beyond glycaemia

- Generalisability of the VERIFY results, i.e., which early combinations to use and how; the role of diagnostic baseline?

- The cost-benefit analyses of various early combinations vs. benefits- would strategic use of combination approach result in cost savings and reduction in complications over time?

Fig. 1. Displaying the factors contributing to our established knowledge base, the unmet clinical needs, how these were modified by the key learnings from the Vildagliptin Efficacy in combination with metfoRmin For earlY treatment of T2DM (VERIFY) study while highlighting the aspects of early diabetes care yet to be explored in the future. 


\section{CAN WE RESCUE THE FAILING $\beta$-CELL?}

Failure of the pancreatic $\beta$-cell to compensate for the progressively increasing insulin resistance has been recognized as the hallmark of T2DM, and the rate of deterioration of glycaemic control parallels that of declining $\beta$-cell function and/or mass $[14,15]$. While prevention of T2DM seems mechanistically feasible, albeit challenging $[16,17]$, attempts to preserve the remaining $\beta$-cell functionality are best undertaken as early along the disease continuum as possible, even if there is limited evidence for identification of the optimal strategy for $\beta$-cell preservation. Some of the best evidence available relates to targeting normoglycemia early, by intensive insulin therapy at the time of diagnosis (Fig. 2) [18]. A shorter time-interval between diagnosis and intensive insulin therapy seem to predict a higher probability for achieving remission up to 2 years [19]. However, clinical implementation of such a regimen might be shadowed by the complexity of a multiple-injection regimen at disease onset, albeit for a short interval. The conceptual success has only been shown in individuals with sustained hyperglycaemia due to delayed diagnosis while dosing of low-dose basal insulin in individuals with newly diagnosed diabetes and low baseline, or pre-diabetes with complications, did not demonstrate impact on $\beta$-cell functionality or disease progression [20]. Additionally, there is no clinical guidance on the most optimal second-line therapy for maintenance of achieved remission after intensive insulin therapy.

Several orally administered drug classes have demonstrated a possible effect on $\beta$-cell preservation. The benefits of thiazolidinediones (TZD) were established when rosiglitazone demonstrated glycaemic durability superior to metformin and glyburide [21] while improvement in $\beta$-cell function was demonstrated to be the predominant underlying pathophysiological mechanism in inducing glycaemic remission from impaired glucose tolerance (IGT) to normal glucose tolerance with pioglitazone, and thus potentially the entire class [22].

Incretin-based therapies have demonstrated the ability to preserve $\beta$-cell function in animal models, although the clinical implication of these preliminary data in human studies is still not fully understood [23-25]. Long-term administration of glucagon-like peptide-1 receptor agonists (GLP-1 RAs) compared with insulin glargine or placebo after 4 weeks of intensive insulin therapy resulted in improved or superior $\beta$-cell function; this effect was either partially maintained [26,27], or lost after cessation of the incretin therapy [28]. Among dipeptidyl pepti- dase-4 inhibitors (DPP-4i) a positive effect on $\beta$-cell function has been shown in numerous clinical studies: treatment with saxagliptin versus placebo resulted in halted reduction in homeostasis model assessment of $\beta$-cell function (HOMA- $\beta$ ) in patients with long-term diabetes and concomitant cardiovascular (CV) disease [29]. An effect that was most pronounced in treatment-naïve patients or those receiving metformin monotherapy. Similar results have been reported in an analysis of all phase III studies of linagliptin on HOMA- $\beta$ versus comparators [30] and with vildagliptin versus placebo, even though this improved effect on $\beta$-cell function was not sustained after a 4 -week washout period [31]. A large meta-analysis of incretinbased therapies on $\beta$-cell and insulin resistance confirmed that these therapies not only demonstrate an increase in HOMA- $\beta$ and fasting C-peptide levels, but also achieve a reduction in insulin resistance (measured as HOMA-IR) and fasting plasma glucose (FPG) in comparison with placebo [25]

Numerous studies have also shown that glucosuric agents such as sodium-glucose cotransporter-2 inhibitors (SGLT-2i), which exert their effect by inhibiting renal glucose reabsorption and producing glucosuria [32], improve insulin secretion by ameliorating the glucotoxic effect of chronic, sustained hyperglycaemia in individuals with T2DM [33-35]. In patients treated with dapagliflozin, insulin secretion significantly increased in a euglycaemic insulin clamp during a standardised oral glucose tolerance test, while there was no amelioration of $\beta$-cell function among patients receiving placebo [36]. The administration of empagliflozin was also shown to improve pancreatic $\beta$-cell function, as measured by the insulin secretion/ insulin resistance index during a hyperglycaemic clamp [33] and the improvement in insulin secretion as induced by another SGLT-2i, ipragliflozin, in Japanese patients was demonstrated to have a more persistent effect even after the cessation of drug administration [34]. In the absence of the SGLT-2 receptors on the islet cells, the exact mechanism beyond removal of the glucotoxicity underlying this beneficial effect of SGLT2 is on insulin secretion remains unknown.

All the evidence indicates that alleviation of sustained hyperglycaemia, regardless of the chosen approach, is the most important contributor to $\beta$-cell preservation. Possibly, targeting normoglycaemia early at disease onset, or even at the prediabetes stage, and maintaining normoglycaemia, safely, by implementing a more aggressive, early therapeutic strategy may change the natural history of disease [9]. The Restoring Insulin Secretion (RISE) Adult Medication Study assessed the 


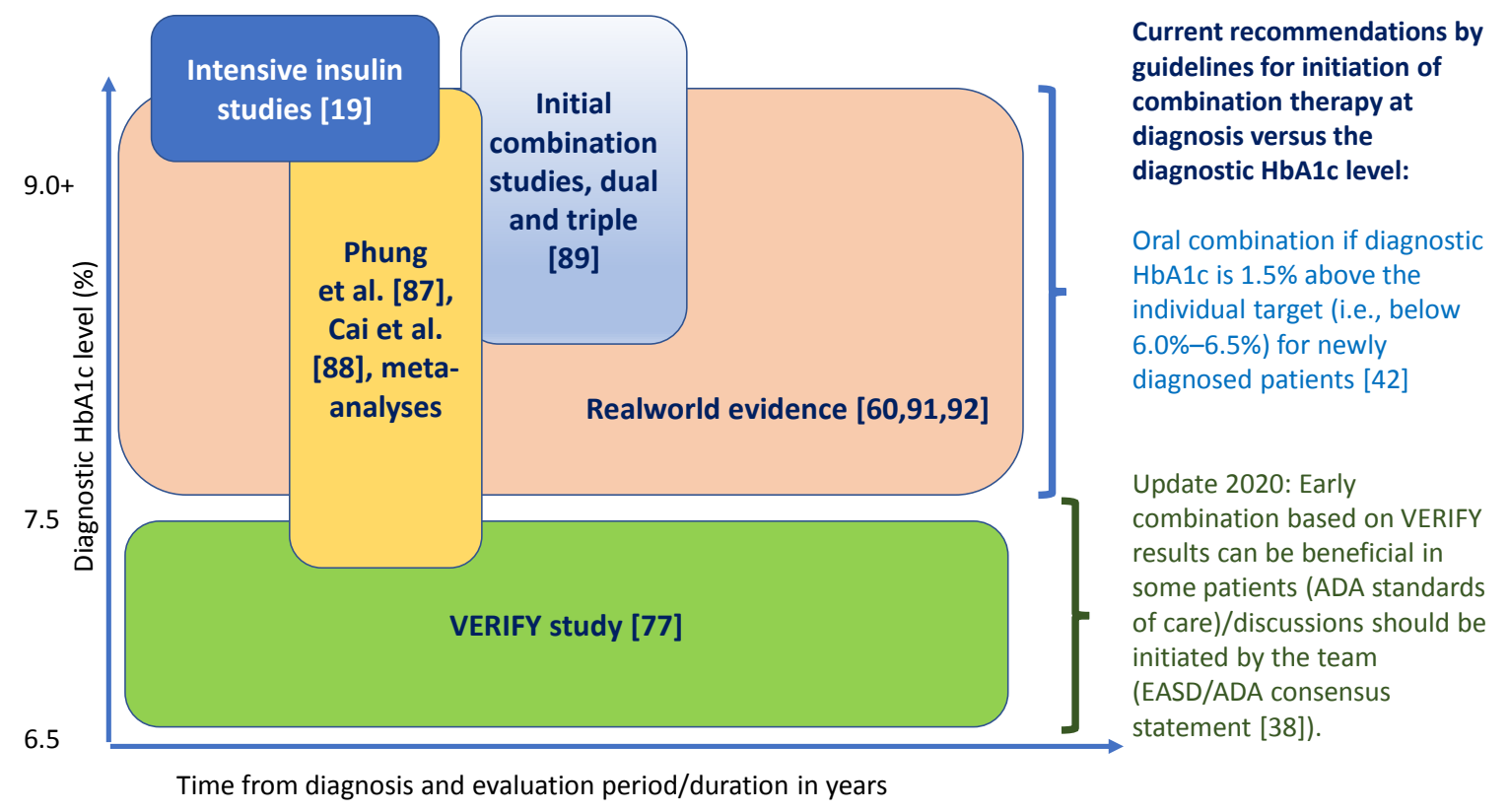

Fig. 2. Theoretical presentation of the available key evidence along the axis of the extent of glycaemia at diagnosis contrasted against the (known/assumed) duration of the disease at the time of confirmed diagnosis (with corresponding reference). HbA1c, glycosylated hemoglobin; VERIFY, Vildagliptin Efficacy in combination with metfoRmin For earlY treatment of T2DM; ADA, American Diabetes Association; EASD, European Association for the Study of Diabetes.

benefit of metformin, GLP-1 RAs, or insulin glargine on $\beta$-cell function in early diabetes. It included a cohort of 10 to 19 -yearold children and adolescents [35], and measured $\beta$-cell function in individuals with IGT or newly diagnosed T2DM. Again, the results demonstrated that $\beta$-cell function improved through active treatment, but the favourable effect was lost after the treatment was stopped. The study results were also indicative of an unmet need for alternative approaches in the youth cohort due to a more aggressive form of the disease in youth [37]. In summary, all of the studies to date have reported on differences in outcomes based on specific individual used, not the timing or combination of therapies.

\section{IMPACT OF CURRENT SEQUENTIAL MONOTHERAPY TREATMENT STRATEGY ON THE EARLY COURSE OF THE DISEASE}

In T2DM, the treatment goals are linked to prevention or delay of chronic complications and maintenance of the patients' quality of life [38]. Therefore, treating to target HbA1c levels is fundamental to achieving disease control, i.e., reducing time spent in hyperglycaemia and preventing chronic, micro- and macrovascular complications and premature mortality [39-41]. Pre- viously, due to lack of sufficient evidence on the use of early combination therapy, stepwise treatment intensification has been the standard approach to achieve glycaemic control as recommended by the American Diabetes Association (ADA)/ European Association for the Study of Diabetes (EASD) consensus on treatment algorithm [42]. The standard of care for first-line drug therapy has been metformin monotherapy with lifestyle measures followed by step-wise treatment intensification to achieve stringent $\mathrm{HbA} 1 \mathrm{c}$ targets (mostly; HbAlc <7.0\%). However, the recent inclusion of $\mathrm{CV}$ status of the patient has added new nuances to the recommendations. The European Society of Cardiology (ESC) guideline developed in collaboration with EASD suggested that instead of metformin, SGLT-2i, and GLP-1 RAs should be administered as first-line monotherapy in patients with atherosclerotic CV disease or with high CV risk [43]. It is recommended that this monotherapy approach, independent of choice of therapy, should be intensified with an additional drug if monotherapy does not achieve or maintain the individualised HbAlc target after 3 months [44]. The preferred third-line treatment approach includes insulin initiation or a triple combination of oral blood glucose lowering drugs $[42,44]$.

Despite these updated recommendations, metformin is still 
the most common initial monotherapy and it will celebrate its 100th birthday in 2022 without a detailed mode of action ever being described. It does, however, have many desirable pharmacodynamic effects: it lowers both basal and postprandial plasma glucose, suppresses excessive hepatic glucose production through a reduction in gluconeogenesis increases glucose uptake and insulin signalling, decreases fatty acid and triglyceride synthesis and increases fatty acid $\beta$-oxidation [45-47]. It may also increase glucose utilisation in peripheral tissues $[45,46]$, and reduce food intake and intestinal glucose absorption, and has been reported to increase the concentration of both incretin hormones (enhance DPP- 4 activity and intact GLP-1 concentrations) and even stimulate GLP-1 synthesis or inhibiting DPP-4 activity (through improved metabolic control) [48]. In other words, metformin, despite being a widely used drug with an impressively complex, dose- and duration dependent effect on glycaemia [49], it is still 'only' a single component and usually a starting point for a series of failing therapy options. We should, instead, consider the favourable effects of a strategic approach, as there are challenges with the metformin, or indeed any, monotherapy approach: non-response on an individual and population level [50], on top of often delayed diagnosis [51].

Our understanding of the genetic basis of T2DM is expanding with nearly 80 susceptibility loci identified, and attempts have been made to correlate phenotype of glucose disposition with particular genotypes [52,53]. Accordingly, the individual response to medications differs from one patient to another. Clinical variables such as disease duration, age, baseline $\mathrm{HbA1c}$, and body mass index have been found to predict clinical responses to metformin, and sulfonylureas (SUs), basal insulin, or incretin-based therapies, whereby the clinical responses to each medication was differently affected by these variables [54-56]. In addition, the field of pharmacogenomics in diabetes is expanding with identification of susceptibility loci to individual drug classes [57]. This means that when most patients present with an $\mathrm{HbAlc}$ value more than $1.5 \%$ to $2 \%$ units of HbAlc above the diagnostic criteria and treatment target level for newly diagnosed patients at diagnosis, the current recommendations for monotherapy limit realistic opportunities to sufficiently lower glycaemia to achieve target levels at onset of diagnosis [10,58]. Furthermore, once diagnosed, many patients with T2DM will likely experience one treatment failure after another, often due to delayed intervention. In a substantial number of newly diagnosed patients, their treating physicians fail to intensify therapy within 6 or even 12 months of failure of metformin monotherapy [59] and less than half of the individuals with self-reported diabetes are likely to achieve the goal of HbA1c below 7.0\% [60] while more than a third will have an $\mathrm{HbA1c}$ value above 7.0\% [61].

\section{CLINICAL INERTIA AS A BARRIER TO OPTIMAL DISEASE OUTCOMES}

The inability to achieve target glycaemic control is multifactorial and includes procrastination by the patient, physician and society [62]. These factors include the difficulty for the person living with diabetes to understand importance of glycaemic control, leading to unrealistic expectations that the condition will resolve spontaneously, rather than progressively worsening over decades $[63,64]$. The 'wait and see' approach of the sequential treatment intensification also creates uncertainties for the undecided physician. Clinical inertia-a failure to initiate or intensify treatment in a timely manner, but also, failure to establish appropriate targets and to escalate treatment to achieve treatment goals [65] - is common and may expose patients to long-term elevation of glycaemia that can negatively impact their prognosis [64]. In reality, median time to treatment intensification, unfortunately, exceeds 12 months even after persistent $\mathrm{HbAlc}$ above $7.0 \%$ for 6 months on metformin monotherapy [66]. Insufficient adherence to "goal setting" and lack of adequate patient-physician communication were proposed to be contributors to clinical inertia according to results of an online patient-physician survey [64]. Though physicians well appreciated the risks associated with poor diabetes control, only $25 \%$ of people living with T2DM reported they were worried about developing diabetes complications, whereas the rest were unconcerned or believed the risk was remote [64]. Clinical inertia seems to accelerate rather than diminish [67, 68] despite the recent focus on it on guidelines [42].

Initiation of combination therapy, or earlier intensification of the failing monotherapy might also be linked to an unfounded fear of potentially increased risk of (potential synergistic) adverse events of multiple regimens [69]. As a result, patients may be exposed to prolonged, avoidable hyperglycaemia prior to treatment intensification, which can lead to increased risk of microvascular and macrovascular complications $[62,70]$. With the onset of complications, therapy intensification can become complex with increased risk of adverse drug reactions [71]. In these circumstances, providers should 
consider first whether aggressive treatment with the goal of attaining lower $\mathrm{HbAlc}$ values is warranted. Nonetheless, the vast majority of newly diagnosed patients with T2DM do not fall into this category and will require, as well as better tolerate, a more aggressive treatment approach. Individuals who are diagnosed with T2DM today might live longer with their disease than they lived without it. Due to earlier disease onset, elevated number of people with young onset diabetes, we have an increasing number of people living with sub-optimally managed T2DM for several decades [72].

\section{COMBINATION THERAPY AT DISEASE ONSET A NEW PARADIGM?}

A proactive approach to treatment intensification was proposed more than 10 years ago as an attempt to minimise time spent in a constant state of hyperglycaemia [73]. During this time, the ADA/EASD/American Association of Clinical Endocrinologists (AACE) treatment guidelines started to support initiation of metformin therapy at diagnosis parallel to lifestyle modification $[74,75]$. Initial combination therapy was to be considered in individuals with an HbAlc above 7.5\% [74] or 9.0\% [75] and later the associations added a text indicating that 'Initial combination therapy may be considered in patients presenting with HbA1c levels more than $17 \mathrm{mmol} / \mathrm{mol}$ (1.5\%) above their target' [38]. It follows that an initial combination regimen was already recommended for use in patients with diagnostic HbAlc value above 7.5\% (Fig. 2).

Thus, the debate started to centre on the need for combination therapy at higher initial levels of HbAlc, and whether at least for those levels indicative of delayed diagnosis or more aggressively progressing early disease, initiating combination therapy based on pathophysiology is preferred over adding stepwise therapy based on demanding glycaemic goals. However, it was less clear is whether initial combination therapy would carry greater benefits than a sequential approach in timely diagnosed, mostly asymptomatic individuals presenting with $\mathrm{HbAlc}$ levels close to or at the diagnostic criteria (HbAlc $6.5 \%)$. Given this dilemma, a study was needed to verify if an early combination strategy provided more favourable outcomes and if the achieved effect on glycaemia could be more durable versus the recommended sequential therapy [76]. A theoretical presentation of the available evidence, with the diagnostic level of glycaemia contrasted against the known or assumed duration of T2DM, both from double-blinded, ran- domised clinical studies but also, real-world evidence and conceptual attempts to rejuvenate the $\beta$-cell functionality in newly diagnosed patients, is displayed in Fig. 2.

\section{VERIFY'ING THE BENEFITS OF EARLY COMBINATION THERAPY APPROACH}

The multinational VERIFY study provides the most compelling evidence regarding opportunities for treatment optimisation in early T2DM [77]. VERIFY enrolled patients who were diagnosed with T2DM within 24 months; HbA1c levels between $6.5 \%$ and $7.5 \%$; no prior diabetes treatment or maximum of 4 weeks of metformin. The study was reflective of the increasingly heterogeneous worldwide T2DM population and enrolled a cohort with ethnic, gender, regional, and socioeconomic diversity $-40 \%$ of the recruited patient population were non-Caucasian and over half were female [78]. The choice of exploring the early combination of a DPP-4i with metformin was supported by the complementary mode of action of its two components; glucose-dependent $\beta$-cell stimulation by vildagliptin [79] and concomitant insulin sensitisation by metformin [80]; as well as the established favourable safety profile of both drugs [81]. Both components have also been reported to reduce hepatic glucose production $[10,80,82]$; a key component and driver of early, progressive T2DM.

In the VERIFY study, half of the individuals received the early combination immediately after a short, individualised metformin up-titration phase while those patients who initially received metformin monotherapy received the same combination therapy with metformin and vildagliptin following their first treatment failure (HbAlc twice, consecutively, 13 weeks apart above 7.0\%). Apart from halving the risk of glycaemic progression in 5 years following treatment initiation and delaying the time to primary treatment failure with more than 2 years versus the sequential approach, early combination therapy also reduced the risk of time to secondary treatment failure (when all patients were receiving the combination) by $26 \%$ [77]. These results provide an additional, confirmatory piece of evidence to the array of studies previously hinting that only the early normalisation of glycaemia can help to attenuate diabetes progression (Fig. 1) [83,84].

As the clinical response of one individual to a particular medication can differ from the response of another individual, one of the most frequently asked questions is whether all patients will benefit from the early combination strategy. The 
median time to initial treatment failure by strategy in the VERIFY study demonstrated the overall lack of benefit with initial metformin monotherapy, in all systematically studied global populations and predefined sub-groups [85]. Additionally, the time to second failure analysis confirmed that better late than never does not apply in diabetes: later introduction of the combination strategy did not provide long-term durability after sequential introduction of a second-line agent. In this way, the full efficacy of the added-on medication, vildagliptin, did not fully materialise versus how efficaciously it induced a rapid reduction in hyperglycaemia but also, provided a remission-like, long-term durability over 5 years when dosed as early combination instead. It also seems impossible to predict on the individual level who will respond to metformin monotherapy; the HbA1c levels were significantly lower throughout 5 years in those receiving the combination strategy versus those who could be considered as 'metformin responders.' Therefore there were very few indicators of superior benefits with initial monotherapy strategy in the VERIFY study. All the clinical benefits, including the intriguing, statistically non-significant trend for improved CV outcomes, were observed among those with early combination despite some individuals having demonstrated relatively good glycaemic control on initial metformin monotherapy [77].

Two synergistic drugs dosed earlier is better [86] and provides a more pronounced and rapid decline in glycaemia than one [77] but the clinically compelling outcomes of the VERIFY study extend beyond the scientific findings. That is, that early combination treatment in newly diagnosed patients with earlystage T2DM provides increased glycaemic durability of target HbA1c levels. VERIFY also demonstrated that achieving these targets required less frequent interventions, and thereby investment of clinical resources, for treatment intensification over time.

\section{SUPPORTING EVIDENCE FOR INITIAL COMBINATION}

Similar results to those of VERIFY have been observed in a meta-analysis of 15 randomised clinical trials evaluating initial, metformin-based, dual combination therapies versus metformin monotherapy in treatment-naïve patients with T2DM (Fig. 2) [87]. Compared with metformin, the combination regimens with TZDs, insulin secretagogues, DPP-4is or SGLT-2is provided statistically significant, albeit absolutely modest re- ductions in $\mathrm{HbA1c}(-0.43 \%$; $95 \%$ confidence interval [CI], -0.56 to -0.30$)$, increases in attainment of glycaemic goal, HbA1c below $7.0 \%$ (relative risk, $1.40 ; 95 \%$ CI, 1.33 to 1.48 ) and reductions in FPG [87]. The population included had a mean age range of 48.4 to 62.7 years; $\mathrm{HbA1c}$ between $7.2 \%$ to $9.9 \%$ and T2DM duration of 1.6 to 4.1 years, with median follow-up of 6 months. Similarly, Cai et al. [88] demonstrated in a meta-analysis of 36 studies with most widely used therapeutic regimens, that compared with metformin monotherapy, initial metformin-based combination therapies exhibited significant reductions in $\mathrm{HbA1c}$ (Fig. 2). In this analysis, most of the combination therapies induced a similar risk of hypoglycaemia, with the exception of combinations of SU/glinide and metformin or combinations of TZD and metformin. Compared with DPP-4i monotherapy, initial DPP-4i-based dual combination therapies showed a significant decrease in $\mathrm{HbA} 1 \mathrm{c}$ and a similar risk of hypoglycaemia [88].

\section{EVIDENCE SUPPORTING EARLY, TIMELY, INTENSIFICATION}

Addressing complex pathophysiological mechanisms may also require acceleration from dual to triple combination: AbdulGhani et al. [89] evaluated initial combination therapy with metformin, TZD (pioglitazone) and a GLP-1 RA (exenatide) compared with add-on therapy to metformin with an SU and then insulin (Fig. 2). In this study, as opposed to the initial triple therapy, the conventional approach began with metformin up-titration, followed by addition of the SU and ultimately, insulin glargine. Interestingly, the time-related change in glycaemia was equally effectively managed with a rather aggressive but efficaciously administered sequential therapy during the first 6 months [89]. However, over time the HbA1c control with the initial triple therapy was superior, due to the components used and the complementary mechanisms of action while the role of the timing of addition of the components was unclear. In other words, this study demonstrated that appropriate, timely intensification of sequential titration of therapy may also lead to achievement of glycaemic targets. Therefore, starting with initial combination therapy may not necessarily fully resolve the issue of clinical inertia still prevalent outside clinical trials [90], but, rather, just postpone it to the next stage of required treatment intensification.

Nevertheless, the benefits of early, timely, therapy intensification are additionally supported by a number of real-world 
studies (Fig. 2). In patients newly diagnosed with T2DM, early intensification of diabetes therapy (timely addition of anti-diabetes medicine, changes in metformin regimen, or nutritionist/dietician referral) due to metformin failure resulted in a more rapid attainment of $\mathrm{HbAlc}$ goals compared with late or no treatment intensification [59]. Real-world observational studies have shown the benefit of intensifying therapy with basal insulin earlier in the treatment paradigm: in an analysis of a US managed-care claims database, earlier insulin initiation in T2DM patients on one or two oral anti-diabetic (OAD) medications at baseline resulted in the greatest reductions in $\mathrm{HbA1c}$, compared with patients on three or more OADs [91] In another retrospective database analysis, significantly more patients on one OAD at baseline (early insulin initiation group) achieved their glycaemic target, compared with patients receiving two, or three or more OADs before insulin initiation; in addition, decrease in $\mathrm{HbA1c}$ was significantly greater in patients on one OAD at baseline [92].

\section{GENERALISABILITY TO, AND SAFETY OF, ALL THE OTHER COMBINATIONS?}

Mechanistically, the effects of agents other than vildagliptin in combination with metformin, or other oral regimens, based on rational consideration of mode of action will provide further insight into pathophysiological processes in early T2DM. Nevertheless, generalisability of the VERIFY results remains to be demonstrated for all the other combinations because numerous studies addressing the same scientific question have contributed to pronounced differences observed in both the efficacy, and safety and tolerability profile of components within the same drug class [93].

The particular drugs and combinations assessed need to be studied comparatively evaluating their short-term effectiveness in $\mathrm{HbA1c}$ reduction as well as their long-term benefits on $\beta$-cell function, durability, and reduction of diabetic complications [94]. Overall, the risk-to-benefit ratio of each drug must be carefully weighed, because patients with newly diagnosed diabetes make up a vulnerable population. Initial combination therapy entails prescription of multiple drug classes with their accordant known and unknown risks in previous exposed or less studied populations. Prescribing incompatible medications may result in unduly exposing many individuals to harm, as the long-term safety of anti-diabetes medications in newlydiagnosed patients has yet to be determined for all (due to ex- tensive focus on CV outcomes trials and later stage patients, mostly in the Western world).

\section{Building on metformin}

Initial or early combination regimens with metformin seem like the most obvious option due to the established role of metformin. although it must be remembered that approximately $5 \%$ to $10 \%$ of individuals cannot tolerate metformin therapy [95]. Therefore alternative combinations excluding metformin should be explored as well, though their current use as firstline therapy is very limited.

The pancreatic and overall safety of incretin-based therapies, a commonly proposed second-line therapy, has increasingly been established even before the reassuring VERIFY results confirming lack of increased risk of pancreatitis in those with newly diagnosed disease [77,96-100]. The combination of metformin and DPP-4i is widely used and is available as a combination pill, thus enhancing patient compliance [101-104]. However, real-world evidence has demonstrated that the prescription of combination pills versus single components is not driven by individual patient-related determinants; surprisingly, the glycaemic goals were equally often reached independent of the formulation used [105]. A meta-analysis including five studies comparing initial combination therapy versus metformin monotherapy demonstrated superior HbAlc and better FPG reductions but lower weight loss [106]. Even though these studies were conducted in individuals with higher baseline $\mathrm{HbAlc}$ levels, similar to the VERIFY results, the initial combination therapy with metformin and a DPP-4i did not induce an increased risk of hypoglycaemia or other anticipated adverse drug reactions such as those related to gastrointestinal side effects [106]. The use of sub-maximal doses of anti-hyperglycaemic agents in combination has been shown to result in similar or superior efficacy compared with monotherapy or up-titration of a single drug, without significantly increasing adverse events [102].

The use of TZDs has become restricted because of safety issues [107] and the use of SUs had been declining in developed areas due to elevated risk of hypoglycaemia and unresolved CV safety issues [108] before the Cardiovascular Outcome Study of Linagliptin vs Glimepiride in Type 2 Diabetes (CAROLINA) study confused the scientific audience with rather neutral CV outcomes, despite a higher rate of hypoglycaemia, in comparison to those receiving linagliptin in a vulnerable patient population with long-term T2DM and chronic renal disease [109]. 
Combination of metformin with TZDs has been studied in multiple trials and increasingly again in real-world setting as the class is generically available. Though the results of these trials are positive, demonstrating better $\mathrm{HbAlc}$ reduction with the fixed-dose combinations [110,111], safety aspects [107] surrounding the drug class have significantly restricted its use despite interesting data regarding the effect of pioglitazone in primary prevention of cerebrovascular disease in individuals with insulin resistance [112]. The combination of pioglitazone and DPP-4is has been studied as well $[113,114]$. Better HbA1c reduction was perceived with the combination, yet weight gain was greater with the combination versus pioglitazone alone in some of the trials. The utility of this combination as first-line therapy is limited and restricted to those who cannot tolerate metformin or have a contraindication to its use.

SGLT-2is have exciting data especially in later populations with concomitant CV disease [115], while reports of euglycaemic ketoacidosis and genitourinary tract infections warrant careful patient selection and better delineation of the populations who may be at risk $[116,117]$. However, knowledge of the reduced pathogenesis when combined with DPP-4is regarding infections favours the use of these agents together [118], even as initial combination albeit the evidence is yet to be generated. The glucosuric effect of SGLT-2is is accompanied by an increased rate of endogenous glucose production which offsets the glucose-lowering effect of SGLT-2is by approximately $50 \%$ [119]. Initial combination therapy of empagliflozin/linagliptin has demonstrated superior $\mathrm{HbA1c}$ reduction versus linagliptin alone, yet the efficacy of high dose empagliflozin was similar to its combination with linagliptin [120]. Potentially the increased glucosuria observed with high-dose SGLT-2is, in particular when prescribed to individuals with high baseline $\mathrm{HbA1c}$, may cause a reciprocal elevation in endogenous glucose production which is beyond the capacity of DPP-4i to overcome [120]. Contrary to the partially negative results of the initial combination therapy, use of a combination of empagliflozin and linagliptin as a second-line therapy, after metformin, yielded positive results, demonstrating superiority of the combination over empagliflozin alone [120]. The encouraging CV data with dapagliflozin in Dapagliflozin Effect on Cardiovascular Events (DECLARE) study [121] contrasted with the findings in the VERIFY study for vildagliptin could induce projections of a promising therapeutic modality as an early combination. However, it remains to be demonstrated to what extent any of these pathophysiological mechanisms of recipro- cal effect on endogenous glucose production would affect the long-term clinical glucose-lowering potency of this combination on lower glycaemic levels closer to normoglycaemia.

The SGLT-2is are available as single pill combination therapies with metformin (and even as triple combinations), competing with the metformin-DPP-4i combination pills as possible first-line initial combination therapy. When used as indicated, both options have minimal drug-induced side effects, beyond those of metformin alone, and most importantly, do not cause hypoglycaemia [122]. Significant weight loss is observed with the combination of SGLT-2is and metformin, whereas weight neutrality or minimal weight gain is observed with the combination of DPP-4i and metformin [106].

\section{CHANGING GUIDELINES ALONE IS NOT ENOUGH}

One of the paradoxes of diabetes management is that early drug treatment is assumed to be considerably less complex than late intervention. Yet the foundation of care is set at the time of diagnosis and more explicit clinical guidance is needed when introducing a new treatment paradigm, a strategy. Using two drugs with complementary mechanisms of action targeting different physiological abnormalities will be required in most patients to achieve adequate glycaemic targets, prevent $\beta$-cell failure and achieve durability versus what can be achieved with the current standard-of-care.

Implementing the current, updated treatment recommendations in practice will require a change, from identification and diagnosis to patient follow-up. Recommendations and tangible protocols will need to facilitate early T2DM detection and diagnosis: one of the past and future challenges of successful replication of the VERIFY study results in practice will be related to underdiagnosis and delayed diagnosis of T2DM worldwide [1]. In VERIFY, only half of the screened individuals met the glycaemic inclusion criteria reflective of optimal diagnostic range and glycaemic levels for disease-modifying effect for preservation of the $\beta$-cells. The lowest individual HbAlc values at screening (after a locally confirmed diagnosis of T2DM) were within the normoglycaemic range $(<5.5 \%)$ while the highest value was beyond the upper limit of the central laboratory ( $>18.5 \%$ ) [123]. There were significant geographical variations, with the absolute screening failure rate indicating over $80 \%$ being outside the desired range [123]. This may be due to regional differences in aptitude of healthcare systems to identi- 
fy patients early; less structured and limited access to public healthcare infrastructure, socioeconomic inequality in combination with less accurate early identification and late or missed diagnoses, confirm the existence of clinical diagnosis inertia and the unmet need for early diagnosis and intervention to curb the epidemic of diabetes. Despite the VERIFY results indicating early benefits (and other evidence indicative of opposite prospects for treatment success for those with delayed diagnosis), the guidelines will need to provide more explicit guidance for early disease detection.

\section{ADDITIONAL CONSIDERATIONS AND UNANSWERED QUESTIONS}

Under recent clinical guidance, and not least based on the results from the VERIFY study, the role of metformin as the cornerstone of early diabetes care requires careful reassessment, among many new questions of importance (Fig. 1). The latest revisions of the guidelines already indicated that eventually UKPDS is the only study which has demonstrated signs of CV risk reduction with metformin while all the other evidence indicates presence of a summarised, neutral effect [124]. It is indeed prime time to explore outcomes of other early combinations without the current widely used component of metformin.

Nevertheless, even if outcomes have gained in importance, one should not conceptually mix outcomes with the clinical determinants of safety and their role in success of any chosen regimen(s). The VERIFY results include an excellent tolerability profile and lack of discontinuations due to adverse events, despite achievement of low, pre-diabetic glycaemic levels [77]. We also learned that every agent added will not necessarily result in additional drug-induced adverse effects in all patients even if there are historical data indicating that adverse drug reactions with older drugs were more prevalent with two-drug combinations as opposed to monotherapy [125]. Conservatively, sequential use and titration of therapy, if applicable, will allow physicians to judge the adverse effect profile of each agent and address it appropriately, whereas use of well-tolerated modern anti-diabetic agents should remove this clinical challenge and, often unconscious fear without foundation. Use of sequential therapy will add to the complexity of the regimen and potentially negatively influence compliance without a favourable effect on safety and tolerability. No evidence exists that would suggest that earlier combination of therapy as opposed to sequential titration would result in greater adherence or compliance of patients. The two different treatment arms in the VERIFY study had similar adherence to the therapeutic regimens in a double-blind setting, and randomised clinical trials can seldom address adherence in an optimal way. Claims of initial combination therapy masking an excellent response to one element of the combination, or a poor response to another, has been rejected as a hypothesis, at least in the VERIFY study [77]. Additionally, there is no evidence to date that a change of timing of the same agents as early combination as opposed to sequential titration of therapy will have any favourable benefits on body weight. Adding an SU earlier in the course may increase weight gain earlier, but if aggressive titration is achieved over a few months, the impact of weight gain and its timing will be minimal. With use of SUs or e.g., insulins, hypoglycaemia would be an issue regardless of timing. Instead, unselective use of early combination therapy may ignore the heterogeneous presentation of the disease at onset and result in pathophysiologically incorrect treatment of individuals from the start-identification of individual drivers of the disease and the best combination components will induce durability and be the first step towards precision medicine. It is hardly justifiable to believe that newly diagnosed patients will maintain adequate glycaemic control with monotherapy or even just by lifestyle modification for a prolonged period of time. One would be ignoring the progressive nature of the disease and the current evidence demonstrating durability for the first time, with potential to reduce the clinical inertia associated with starting and optimising glycaemic control.

It could be argued that the narrow baseline glycaemia in the VERIFY study was not reflective of clinical reality but in the future, physicians may also face challenges in justifying continued treatment when impressive glycaemic control on or close to normoglycaemic levels have been achieved and diabetes 'remission' has been coined as a term. As T2DM is a progressive disease with underlying mechanisms for complications and early loss of $\beta$-cell function and insulin sensitivity, cessation of successful treatment and 'drug-holidays' justified by financial claims will jeopardise the unique response to early combination treatment. Therefore, we must shift from a concept of sequential treatment failures to new concepts of long-term diabetes remission, disease modifying effect and conversion of glycaemia back to pre-diabetic levels.

There are several studies estimating the cost-effectiveness of the new anti-diabetes agents, not strategic approaches, and it is difficult to quantify the cost-effectiveness of softer outcomes 
such as fewer hypoglycaemic events or improved quality of life [126]. Conceptually, initial combination therapy may induce wider clinical use of newer and more costly anti-diabetes agents. However, its cost-effectiveness must be individually assessed against the known, currently progressive disease management strategies, and generated costs, which are often covered out of pocket by the individual instead of the society potentially reimbursing for the drug. The cost of these novel agents remains a significant hurdle to their clinical use in many regions of the world. The emerging evidence for long-term efficacy and safety out of the VERIFY study now provides preliminary data on the impact of excess time spent in avoidable hyperglycaemia using validated pharmaco-economic models. Increasing awareness of the benefits of sustained and continuous disease control is essential to achieve alignment between physicians and policy makers. The incoming Glycemia Reduction Approaches in Diabetes: a Comparative Effectiveness (GRADE) study will additionally respond to many of these questions [94].

\section{CONCLUSIONS}

The recently reported VERIFY study results have provided a wealth of new evidence confirming long-term glycaemic durability and tolerability of the studied early combination in the management of newly diagnosed, treatment-naïve patients worldwide. These results have also contributed to changes in clinical treatment guidelines and standards of care. Clinical implementation and individualised treatment decisions based on VERIFY results might face barriers beyond the existing scientific evidence. Appropriate, timely intensification of sequential titration of therapy may also lead to achievement of glycaemic targets while there is a wealth of data indicating this approach is challenging and less successful in clinical practise due to extensive presence of clinical inertia. While there is no single answer to the question if the early combination genuinely and always is better, in all individuals, these unanswered questions, as highlighted in the current diabetes guidelines, should not become obstacles when changing the practice of medicine, one patient at a time, when carefully considering each individual case.

\section{CONFLICTS OF INTEREST}

Päivi Maria Paldánius was the medical lead of the VERIFY study and employee of Novartis Pharma AG at the time of
VERIFY study conduction and up to initial study results reporting until January 2020.

\section{ORCID}

Päivi Maria Paldánius https://orcid.org/0000-0001-5997-4879

\section{ACKNOWLEDGMENTS}

None

\section{REFERENCES}

1. International Diabetes Federation. IDF diabetes atlas. 9th ed. Brussels: International Diabetes Federation; 2019.

2. Ma RC, Chan JC. Type 2 diabetes in East Asians: similarities and differences with populations in Europe and the United States. Ann N Y Acad Sci 2013;1281:64-91.

3. Chan JC, Malik V, Jia W, Kadowaki T, Yajnik CS, Yoon KH, $\mathrm{Hu}$ FB. Diabetes in Asia: epidemiology, risk factors, and pathophysiology. JAMA 2009;301:2129-40.

4. Yoon KH, Lee JH, Kim JW, Cho JH, Choi YH, Ko SH, Zimmet P, Son HY. Epidemic obesity and type 2 diabetes in Asia. Lancet 2006;368:1681-8.

5. Tuomi T, Santoro N, Caprio S, Cai M, Weng J, Groop L. The many faces of diabetes: a disease with increasing heterogeneity. Lancet 2014;383:1084-94.

6. Kahn SE. The relative contributions of insulin resistance and beta-cell dysfunction to the pathophysiology of type 2 diabetes. Diabetologia 2003;46:3-19.

7. Zhou K, Donnelly LA, Morris AD, Franks PW, Jennison C, Palmer CN, Pearson ER. Clinical and genetic determinants of progression of type 2 diabetes: a DIRECT study. Diabetes Care 2014;37:718-24.

8. Defronzo RA. Banting lecture. From the triumvirate to the ominous octet: a new paradigm for the treatment of type $2 \mathrm{di}-$ abetes mellitus. Diabetes 2009;58:773-95.

9. Phillips LS, Ratner RE, Buse JB, Kahn SE. We can change the natural history of type 2 diabetes. Diabetes Care 2014;37: 2668-76.

10. DeFronzo RA, Eldor R, Abdul-Ghani M. Pathophysiologic approach to therapy in patients with newly diagnosed type 2 diabetes. Diabetes Care 2013;36 Suppl 2:S127-38.

11. Schnell O, Barnard K, Bergenstal R, Bosi E, Garg S, Guerci B, Haak T, Hirsch IB, Ji L, Joshi SR, Kamp M, Laffel L, Mathieu 
C, Polonsky WH, Snoek F, Home P. Clinical utility of SMBG: recommendations on the use and reporting of SMBG in clinical research. Diabetes Care 2015;38:1627-33.

12. Nalysnyk L, Hernandez-Medina M, Krishnarajah G. Glycaemic variability and complications in patients with diabetes mellitus: evidence from a systematic review of the literature. Diabetes Obes Metab 2010;12:288-98.

13. Garber AJ, Abrahamson MJ, Barzilay JI, Blonde L, Bloomgarden ZT, Bush MA, Dagogo-Jack S, DeFronzo RA, Einhorn D, Fonseca VA, Garber JR, Garvey WT, Grunberger G, Handelsman Y, Hirsch IB, Jellinger PS, McGill JB, Mechanick JI, Rosenblit PD, Umpierrez GE. Consensus statement by the American Association of Clinical Endocrinologists and American College of Endocrinology on the comprehensive type 2 diabetes management algorithm: 2017 executive summary. Endocr Pract 2017;23:207-38.

14. Gastaldelli A, Ferrannini E, Miyazaki Y, Matsuda M, DeFronzo RA; San Antonio metabolism study. Beta-cell dysfunction and glucose intolerance: results from the San Antonio metabolism (SAM) study. Diabetologia 2004;47:31-9.

15. Meier JJ, Bonadonna RC. Role of reduced $\beta$-cell mass versus impaired $\beta$-cell function in the pathogenesis of type 2 diabetes. Diabetes Care 2013;36 Suppl 2:S113-9.

16. Uusitupa M, Lindstrom J, Tuomilehto J. Prevention of type 2 diabetes-success story that is waiting for next steps. Eur J Clin Nutr 2018;72:1260-6.

17. Halban PA, Polonsky KS, Bowden DW, Hawkins MA, Ling C, Mather KJ, Powers AC, Rhodes CJ, Sussel L, Weir GC. $\beta$-Cell failure in type 2 diabetes: postulated mechanisms and prospects for prevention and treatment. J Clin Endocrinol Metab 2014;99:1983-92.

18. Kramer CK, Zinman B, Retnakaran R. Short-term intensive insulin therapy in type 2 diabetes mellitus: a systematic review and meta-analysis. Lancet Diabetes Endocrinol 2013;1:28-34.

19. Xu W, Li YB, Deng WP, Hao YT, Weng JP. Remission of hyperglycemia following intensive insulin therapy in newly diagnosed type 2 diabetic patients: a long-term follow-up study. Chin Med J (Engl) 2009;122:2554-9.

20. ORIGIN Trial Investigators, Gerstein HC, Bosch J, Dagenais GR, Diaz R, Jung H, Maggioni AP, Pogue J, Probstfield J, Ramachandran A, Riddle MC, Ryden LE, Yusuf S. Basal insulin and cardiovascular and other outcomes in dysglycemia. N Engl J Med 2012;367:319-28.

21. Kahn SE, Haffner SM, Heise MA, Herman WH, Holman RR, Jones NP, Kravitz BG, Lachin JM, O’Neill MC, Zinman B,
Viberti G; ADOPT Study Group. Glycemic durability of rosiglitazone, metformin, or glyburide monotherapy. N Engl J Med 2006;355:2427-43.

22. Defronzo RA, Tripathy D, Schwenke DC, Banerji M, Bray GA, Buchanan TA, Clement SC, Gastaldelli A, Henry RR, Kitabchi AE, Mudaliar S, Ratner RE, Stentz FB, Musi N, Reaven PD; ACT NOW Study. Prevention of diabetes with pioglitazone in ACT NOW: physiologic correlates. Diabetes 2013;62:3920-6.

23. Ahren B. DPP-4 inhibition and islet function. J Diabetes Investig 2012;3:3-10.

24. Drucker DJ. Incretin action in the pancreas: potential promise, possible perils, and pathological pitfalls. Diabetes 2013;62: 3316-23.

25. Wu S, Gao L, Cipriani A, Huang Y, Yang Z, Yang J, Yu S, Zhang Y, Chai S, Zhang Z, Sun F, Zhan S. The effects of incretinbased therapies on $\beta$-cell function and insulin resistance in type 2 diabetes: a systematic review and network meta-analysis combining 360 trials. Diabetes Obes Metab 2019;21:97583.

26. Bunck MC, Corner A, Eliasson B, Heine RJ, Shaginian RM, Taskinen MR, Smith U, Yki-Jarvinen H, Diamant M. Effects of exenatide on measures of $\beta$-cell function after 3 years in metformin-treated patients with type 2 diabetes. Diabetes Care 2011;34:2041-7.

27. Philis-Tsimikas A, Wysham CH, Hardy E, Han J, Iqbal N. Efficacy and tolerability of exenatide once weekly over 7 years in patients with type 2 diabetes: an open-label extension of the DURATION-1 study. J Diabetes Complications 2019;33:22330.

28. Retnakaran R, Kramer CK, Choi H, Swaminathan B, Zinman B. Liraglutide and the preservation of pancreatic $\beta$-cell function in early type 2 diabetes: the LIBRA trial. Diabetes Care 2014;37:3270-8.

29. Leibowitz G, Cahn A, Bhatt DL, Hirshberg B, Mosenzon O, Wei C, Jermendy G, Sheu WH, Sendon JL, Im K, Braunwald E, Scirica BM, Raz I. Impact of treatment with saxagliptin on glycaemic stability and $\beta$-cell function in the SAVOR-TIMI 53 study. Diabetes Obes Metab 2015;17:487-94.

30. Heise T, Larbig M, Patel S, Seck T, Hehnke U, Woerle HJ, Dugi $\mathrm{K}$. The dipeptidyl peptidase-4 inhibitor linagliptin lowers postprandial glucose and improves measures of $\beta$-cell function in type 2 diabetes. Diabetes Obes Metab 2014;16:1036-9.

31. Foley JE, Bunck MC, Moller-Goede DL, Poelma M, Nijpels G, Eekhoff EM, Schweizer A, Heine RJ, Diamant M. Beta cell function following 1 year vildagliptin or placebo treatment 
and after 12 week washout in drug-naïve patients with type 2 diabetes and mild hyperglycaemia: a randomised controlled trial. Diabetologia 2011;54:1985-91.

32. Kalra S. Sodium glucose co-transporter-2 (SGLT2) inhibitors: a review of their basic and clinical pharmacology. Diabetes Ther 2014;5:355-66.

33. Al Jobori H, Daniele G, Adams J, Cersosimo E, Solis-Herrera C, Triplitt C, DeFronzo RA, Abdul-Ghani M. Empagliflozin treatment is associated with improved $\beta$-cell function in type 2 diabetes mellitus. J Clin Endocrinol Metab 2018;103:1402-7.

34. Takahara M, Shiraiwa T, Matsuoka TA, Katakami N, Shimomura I. Ameliorated pancreatic $\beta$ cell dysfunction in type 2 diabetic patients treated with a sodium-glucose cotransporter 2 inhibitor ipragliflozin. Endocr J 2015;62:77-86.

35. RISE Consortium. Restoring Insulin Secretion (RISE): design of studies of $\beta$-cell preservation in prediabetes and early type 2 diabetes across the life span. Diabetes Care 2014;37:780-8.

36. Merovci A, Mari A, Solis-Herrera C, Xiong J, Daniele G, Chavez-Velazquez A, Tripathy D, Urban McCarthy S, AbdulGhani M, DeFronzo RA. Dapagliflozin lowers plasma glucose concentration and improves $\beta$-cell function. J Clin Endocrinol Metab 2015;100:1927-32.

37. RISE Consortium. Impact of insulin and metformin versus metformin alone on $\beta$-cell function in youth with impaired glucose tolerance or recently diagnosed type 2 diabetes. Diabetes Care 2018;41:1717-25.

38. Davies MJ, D’Alessio DA, Fradkin J, Kernan WN, Mathieu C, Mingrone G, Rossing P, Tsapas A, Wexler DJ, Buse JB. Management of hyperglycemia in type 2 diabetes, 2018. A consensus report by the American Diabetes Association (ADA) and the European Association for the Study of Diabetes (EASD). Diabetes Care 2018;41:2669-701.

39. UK Prospective Diabetes Study (UKPDS) Group. Effect of intensive blood-glucose control with metformin on complications in overweight patients with type 2 diabetes (UKPDS 34). Lancet 1998;352:854-65.

40. UK Prospective Diabetes Study (UKPDS) Group. Intensive blood-glucose control with sulphonylureas or insulin compared with conventional treatment and risk of complications in patients with type 2 diabetes (UKPDS 33). Lancet 1998;352: 837-53.

41. Stratton IM, Adler AI, Neil HA, Matthews DR, Manley SE, Cull CA, Hadden D, Turner RC, Holman RR. Association of glycaemia with macrovascular and microvascular complications of type 2 diabetes (UKPDS 35): prospective observation- al study. BMJ 2000;321:405-12.

42. Buse JB, Wexler DJ, Tsapas A, Rossing P, Mingrone G, Mathieu C, D’Alessio DA, Davies MJ. 2019 Update to: management of hyperglycaemia in type 2 diabetes, 2018. A consensus report by the American Diabetes Association (ADA) and the European Association for the Study of Diabetes (EASD). Diabetologia. 2020;63:221-8.

43. Cosentino F, Grant PJ, Aboyans V, Bailey CJ, Ceriello A, Delgado V, Federici M, Filippatos G, Grobbee DE, Hansen TB, Huikuri HV, Johansson I, Juni P, Lettino M, Marx N, Mellbin LG, Ostgren CJ, Rocca B, Roffi M, Sattar N, Seferovic PM, Sousa-Uva M, Valensi P, Wheeler DC; ESC Scientific Document Group. 2019 ESC guidelines on diabetes, pre-diabetes, and cardiovascular diseases developed in collaboration with the EASD. Eur Heart J 2020;41:255-323.

44. American Association of Clinical Endocrinologists: Comprehensive type 2 diabetes management algorithm (2019) executive summary. Available from: https://www.aace.com/diseasestate-resources/diabetes/clinical-practice-guidelines-treatment-algorithms/comprehensive (cited 2020 Aug 19).

45. Hundal RS, Krssak M, Dufour S, Laurent D, Lebon V, Chandramouli V, Inzucchi SE, Schumann WC, Petersen KF, Landau BR, Shulman GI. Mechanism by which metformin reduces glucose production in type 2 diabetes. Diabetes 2000;49: 2063-9.

46. Migoya EM, Miller J, Larson P, Tanen M, Hilliard D, Deacon C, Gutierrez M, Stoch A, Herman GA, Stein PP, Holst JJ, Wagner JA. Sitagliptin, a selective DPP-4 inhibitor, and metformin have complementary effects to increase active GLP-1 concentrations. Diabetes 2007;56(Suppl 1):A74.

47. Dunning BE, Ligueros-Saylan M, D’Alessio DA, Balas B, Kelley DE, Deacon CF, Holst JJ, Foley JE. Differential effects of DPP-4 inhibition on incretin hormone levels in drug-naïve and metformin-treated patients with type 2 diabetes. Diabetologia 2006;49(Suppl 1):110-1.

48. Yasuda N, Inoue T, Nagakura T, Yamazaki K, Kira K, Saeki T, Tanaka I. Enhanced secretion of glucagon-like peptide 1 by biguanide compounds. Biochem Biophys Res Commun 2002; 298:779-84.

49. Rena G, Hardie DG, Pearson ER. The mechanisms of action of metformin. Diabetologia 2017;60:1577-85.

50. Rashid M, Shahzad M, Mahmood S, Khan K. Variability in the therapeutic response of metformin treatment in patients with type 2 diabetes mellitus. Pak J Med Sci 2019;35:71-6.

51. Chen L, Magliano DJ, Zimmet PZ. The worldwide epidemiol- 
ogy of type 2 diabetes mellitus: present and future perspectives. Nat Rev Endocrinol 2011;8:228-36.

52. Kleinberger JW, Pollin TI. Personalized medicine in diabetes mellitus: current opportunities and future prospects. Ann N Y Acad Sci 2015;1346:45-56.

53. Dimas AS, Lagou V, Barker A, Knowles JW, Magi R, Hivert MF, Benazzo A, Rybin D, Jackson AU, Stringham HM, Song C, Fischer-Rosinsky A, Boesgaard TW, Grarup N, Abbasi FA, Assimes TL, Hao K, Yang X, Lecoeur C, Barroso I, Bonnycastle LL, Bottcher Y, Bumpstead S, Chines PS, Erdos MR, Graessler J, Kovacs P, Morken MA, Narisu N, Payne F, Stancakova A, Swift AJ, Tonjes A, Bornstein SR, Cauchi S, Froguel P, Meyre D, Schwarz PE, Haring HU, Smith U, Boehnke M, Bergman RN, Collins FS, Mohlke KL, Tuomilehto J, Quertemous T, Lind L, Hansen T, Pedersen O, Walker M, Pfeiffer AF, Spranger J, Stumvoll M, Meigs JB, Wareham NJ, Kuusisto J, Laakso M, Langenberg C, Dupuis J, Watanabe RM, Florez JC, Ingelsson E, McCarthy MI, Prokopenko I; MAGIC Investigators. Impact of type 2 diabetes susceptibility variants on quantitative glycemic traits reveals mechanistic heterogeneity. Diabetes 2014;63:2158-71.

54. Martono DP, Lub R, Lambers Heerspink HJ, Hak E, Wilffert B, Denig P. Predictors of response in initial users of metformin and sulphonylurea derivatives: a systematic review. Diabet Med 2015;32:853-64.

55. Monami M, Ragghianti B, Zannoni S, Vitale V, Nreu B, Mannucci $E$. Identification of predictors of response to basal insulin and DPP4 inhibitors in patients with type 2 diabetes failing to other therapies. Acta Diabetol 2016;53:35-40.

56. Khan M, Ouyang J, Perkins K, Nair S, Joseph F. Determining predictors of early response to exenatide in patients with type 2 diabetes mellitus. J Diabetes Res 2015;2015:162718.

57. Mannino GC, Andreozzi F, Sesti G. Pharmacogenetics of type 2 diabetes mellitus, the route toward tailored medicine. Diabetes Metab Res Rev 2019;35:e3109.

58. Brown JB, Conner C, Nichols GA. Secondary failure of metformin monotherapy in clinical practice. Diabetes Care 2010; 33:501-6.

59. Pantalone KM, Wells BJ, Chagin KM, Ejzykowicz F, Yu C, Milinovich A, Bauman JM, Kattan MW, Rajpathak S, Zimmerman RS. Intensification of diabetes therapy and time until A1C goal attainment among patients with newly diagnosed type 2 diabetes who fail metformin monotherapy within a large integrated health system. Diabetes Care 2016;39:152734.
60. Stark Casagrande S, Fradkin JE, Saydah SH, Rust KF, Cowie CC. The prevalence of meeting A1C, blood pressure, and LDL goals among people with diabetes, 1988-2010. Diabetes Care 2013;36:2271-9.

61. de Pablos-Velasco P, Parhofer KG, Bradley C, Eschwege E, Gonder-Frederick L, Maheux P, Wood I, Simon D. Current level of glycaemic control and its associated factors in patients with type 2 diabetes across Europe: data from the PANORAMA study. Clin Endocrinol (Oxf) 2014;80:47-56.

62. Khunti K, Wolden ML, Thorsted BL, Andersen M, Davies MJ. Clinical inertia in people with type 2 diabetes: a retrospective cohort study of more than 80,000 people. Diabetes Care 2013; 36:3411-7.

63. Reach G, Pechtner V, Gentilella R, Corcos A, Ceriello A. Clinical inertia and its impact on treatment intensification in people with type 2 diabetes mellitus. Diabetes Metab 2017;43:50111.

64. Strain WD, Cos X, Hirst M, Vencio S, Mohan V, Voko Z, Yabe D, Bluher M, Paldanius PM. Time to do more: addressing clinical inertia in the management of type 2 diabetes mellitus. Diabetes Res Clin Pract 2014;105:302-12.

65. Strain WD, Bluher M, Paldanius P. Clinical inertia in individualising care for diabetes: is there time to do more in type 2 diabetes? Diabetes Ther 2014;5:347-54.

66. Fu AZ, Qiu Y, Davies MJ, Radican L, Engel SS. Treatment intensification in patients with type 2 diabetes who failed metformin monotherapy. Diabetes Obes Metab 2011;13:765-9.

67. Lin J, Zhou S, Wei W, Pan C, Lingohr-Smith M, Levin P. Does clinical inertia vary by personalized A1C goal? A study of predictors and prevalence of clinical inertia in a U.S. managedcare setting. Endocr Pract 2016;22:151-61.

68. Fu AZ, Sheehan JJ. Treatment intensification for patients with type 2 diabetes and poor glycaemic control. Diabetes Obes Metab 2016;18:892-8.

69. Kunt T, Snoek FJ. Barriers to insulin initiation and intensification and how to overcome them. Int J Clin Pract Suppl 2009; 164:6-10.

70. Paul SK, Klein K, Thorsted BL, Wolden ML, Khunti K. Delay in treatment intensification increases the risks of cardiovascular events in patients with type 2 diabetes. Cardiovasc Diabetol 2015;14:100.

71. Action to Control Cardiovascular Risk in Diabetes Study Group, Gerstein HC, Miller ME, Byington RP, Goff DC Jr, Bigger JT, Buse JB, Cushman WC, Genuth S, Ismail-Beigi F, Grimm RH Jr, Probstfield JL, Simons-Morton DG, Friede- 
wald WT. Effects of intensive glucose lowering in type 2 diabetes. N Engl J Med 2008;358:2545-59.

72. Zoungas S, Woodward M, Li Q, Cooper ME, Hamet P, Harrap S, Heller S, Marre M, Patel A, Poulter N, Williams B, Chalmers J; ADVANCE Collaborative group. Impact of age, age at diagnosis and duration of diabetes on the risk of macrovascular and microvascular complications and death in type 2 diabetes. Diabetologia 2014;57:2465-74.

73. Del Prato S, Felton AM, Munro N, Nesto R, Zimmet P, Zinman B; Global Partnership for Effective Diabetes Management. Improving glucose management: ten steps to get more patients with type 2 diabetes to glycaemic goal. Int J Clin Pract 2005;59:1345-55.

74. American Association of Clinical Endocrinologists: AACE/ ACE clinical practice guidelines for developing a diabetes mellitus comprehensive care plan 2015. Available from: https:// www.aace.com/disease-state-resources/diabetes/clinicalpractice-guidelines/aaceace-clinical-practice-guidelines (cited 2020 Aug 19).

75. American Diabetes Association. Approaches to glycemic treatment. Sec. 7. In standards of medical care in diabetes: 2015. Diabetes Care 2015;38(Suppl 1):S41-8.

76. Del Prato S, Foley JE, Kothny W, Kozlovski P, Stumvoll M, Paldanius PM, Matthews DR. Study to determine the durability of glycaemic control with early treatment with a vildagliptinmetformin combination regimen vs. standard-of-care metformin monotherapy-the VERIFY trial: a randomized doubleblind trial. Diabet Med 2014;31:1178-84.

77. Matthews DR, Paldanius PM, Proot P, Chiang Y, Stumvoll M, Del Prato S; VERIFY study group. Glycaemic durability of an early combination therapy with vildagliptin and metformin versus sequential metformin monotherapy in newly diagnosed type 2 diabetes (VERIFY): a 5-year, multicentre, randomised, double-blind trial. Lancet 2019;394:1519-29.

78. Matthews DR, Paldanius PM, Proot P, Foley JE, Stumvoll M, Del Prato S. Baseline characteristics in the VERIFY study: a randomized trial assessing the durability of glycaemic control with early vildagliptin-metformin combination in newly diagnosed type 2 diabetes. Diabet Med 2019;36:505-13.

79. Ahren B, Foley JE. The islet enhancer vildagliptin: mechanisms of improved glucose metabolism. Int J Clin Pract Suppl 2008;159:8-14.

80. Giannarelli R, Aragona M, Coppelli A, Del Prato S. Reducing insulin resistance with metformin: the evidence today. Diabetes Metab 2003;29(4 Pt 2):6S28-35.
81. Matthews DR, Dejager S, Ahren B, Fonseca V, Ferrannini E, Couturier A, Foley JE, Zinman B. Vildagliptin add-on to metformin produces similar efficacy and reduced hypoglycaemic risk compared with glimepiride, with no weight gain: results from a 2-year study. Diabetes Obes Metab 2010;12:780-9.

82. Mathieu C, Degrande E. Vildagliptin: a new oral treatment for type 2 diabetes mellitus. Vasc Health Risk Manag 2008;4:134960.

83. Mosenzon O, Leibowitz G. VERIFY the role of initial combination therapy in patients with type 2 diabetes. Lancet 2019; 394:1483-5.

84. Holman RR, Paul SK, Bethel MA, Matthews DR, Neil HA. 10Year follow-up of intensive glucose control in type 2 diabetes. N Engl J Med. 2008;359:1577-89.

85. Matthews DR, Paldanius PM, Stumvoll M, Han J, Bader G, Chiang Y, Proot P, Del Prato S. A pre-specified statistical analysis plan for the VERIFY study: vildagliptin efficacy in combination with metformin for early treatment of T2DM. Diabetes Obes Metab 2019;21:2240-7.

86. Prattichizzo F, La Sala L, Ceriello A. Two drugs are better than one to start T2DM therapy. Nat Rev Endocrinol 2020;16:1516.

87. Phung OJ, Sobieraj DM, Engel SS, Rajpathak SN. Early combination therapy for the treatment of type 2 diabetes mellitus: systematic review and meta-analysis. Diabetes Obes Metab 2014;16:410-7.

88. Cai X, Gao X, Yang W, Han X, Ji L. Efficacy and safety of initial combination therapy in treatment-naive type 2 diabetes patients: a systematic review and meta-analysis. Diabetes Ther 2018;9:1995-2014.

89. Abdul-Ghani MA, Puckett C, Triplitt C, Maggs D, Adams J, Cersosimo E, DeFronzo RA. Initial combination therapy with metformin, pioglitazone and exenatide is more effective than sequential add-on therapy in subjects with new-onset diabetes. Results from the Efficacy and Durability of Initial Combination Therapy for Type 2 Diabetes (EDICT): a randomized trial. Diabetes Obes Metab 2015;17:268-75.

90. Strain WD, Paldanius PM. Effect of clinical inertia and trial participation in younger and older adults with diabetes having comorbidities and progressive complications. Diabetes Res Clin Pract 2020;166:108310.

91. Levin PA, Zhou S, Gill J, Wei W. Health outcomes associated with initiation of basal insulin after 1,2 , or $\geq 3$ oral antidiabetes drug(s) among managed care patients with type 2 diabetes. J Manag Care Spec Pharm 2015;21:1172-81. 
92. Levin P, Zhou S, Durden E, Farr AM, Gill J, Wei W. Clinical and economic outcomes associated with the timing of initiation of basal insulin in patients with type 2 diabetes mellitus previously treated with oral antidiabetes drugs. Clin Ther 2016;38:110-21.

93. Kluger AY, Tecson KM, Lee AY, Lerma EV, Rangaswami J, Lepor NE, Cobble ME, McCullough PA. Class effects of SGLT2 inhibitors on cardiorenal outcomes. Cardiovasc Diabetol 2019;18:99.

94. Nathan DM, Buse JB, Kahn SE, Krause-Steinrauf H, Larkin ME, Staten M, Wexler D, Lachin JM; GRADE Study Research Group. Rationale and design of the glycemia reduction approaches in diabetes: a comparative effectiveness study (GRADE). Diabetes Care 2013;36:2254-61.

95. Bouchoucha M, Uzzan B, Cohen R. Metformin and digestive disorders. Diabetes Metab 2011;37:90-6.

96. Egan AG, Blind E, Dunder K, de Graeff PA, Hummer BT, Bourcier T, Rosebraugh C. Pancreatic safety of incretin-based drugs: FDA and EMA assessment. N Engl J Med 2014;370: 794-7.

97. Jensen TM, Saha K, Steinberg WM. Is there a link between liraglutide and pancreatitis? A post hoc review of pooled and patient-level data from completed liraglutide type 2 diabetes clinical trials. Diabetes Care 2015;38:1058-66.

98. Mathieu C, Kozlovski P, Paldanius PM, Foley JE, Modgill V, Evans M, Serban C. Clinical safety and tolerability of vildagliptin: insights from randomised trials, observational studies and post-marketing surveillance. Eur Endocrinol 2017;13:6872.

99. Thomsen RW, Pedersen L, Moller N, Kahlert J, Beck-Nielsen $\mathrm{H}$, Sorensen HT. Incretin-based therapy and risk of acute pancreatitis: a nationwide population-based case-control study. Diabetes Care 2015;38:1089-98.

100. Saisho Y. Incretin-based therapy and pancreatitis: accumulating evidence and unresolved questions. Ann Transl Med 2018; 6:131.

101. Williams-Herman D, Johnson J, Teng R, Golm G, Kaufman KD, Goldstein BJ, Amatruda JM. Efficacy and safety of sitagliptin and metformin as initial combination therapy and as monotherapy over 2 years in patients with type 2 diabetes. Diabetes Obes Metab 2010;12:442-51.

102. Bosi E, Dotta F, Jia Y, Goodman M. Vildagliptin plus metformin combination therapy provides superior glycaemic control to individual monotherapy in treatment-naive patients with type 2 diabetes mellitus. Diabetes Obes Metab 2009;11:506-
15.

103. Haak T, Meinicke T, Jones R, Weber S, von Eynatten M, Woerle HJ. Initial combination of linagliptin and metformin improves glycaemic control in type 2 diabetes: a randomized, double-blind, placebo-controlled study. Diabetes Obes Metab 2012;14:565-74.

104. Pfutzner A, Paz-Pacheco E, Allen E, Frederich R, Chen R; CV181039 Investigators. Initial combination therapy with saxagliptin and metformin provides sustained glycaemic control and is well tolerated for up to 76 weeks. Diabetes Obes Metab 2011;13:567-76.

105. Brath H, Paldanius PM, Bader G, Mathieu C. The physician's choice: single pill or fixed-dose combination? 77th Scientific Sessions of the American Diabetes Association (ADA): 2017 Jun 9-13; San Diego, CA.

106. Wu D, Li L, Liu C. Efficacy and safety of dipeptidyl peptidase- 4 inhibitors and metformin as initial combination therapy and as monotherapy in patients with type 2 diabetes mellitus: a meta-analysis. Diabetes Obes Metab 2014;16:30-7.

107. Schernthaner G, Currie CJ, Schernthaner GH. Do we still need pioglitazone for the treatment of type 2 diabetes? A riskbenefit critique in 2013. Diabetes Care 2013;36 Suppl 2:S15561.

108. Abdelmoneim AS, Eurich DT, Light PE, Senior PA, Seubert JM, Makowsky MJ, Simpson SH. Cardiovascular safety of sulphonylureas: over 40 years of continuous controversy without an answer. Diabetes Obes Metab 2015;17:523-32.

109. Rosenstock J, Kahn SE, Johansen OE, Zinman B, Espeland MA, Woerle HJ, Pfarr E, Keller A, Mattheus M, Baanstra D, Meinicke T, George JT, von Eynatten M, McGuire DK, Marx $\mathrm{N}$; CAROLINA Investigators. Effect of linagliptin vs glimepiride on major adverse cardiovascular outcomes in patients with type 2 diabetes: the CAROLINA randomized clinical trial. JAMA 2019;322:1155-66.

110. Rosenstock J, Rood J, Cobitz A, Biswas N, Chou H, Garber A. Initial treatment with rosiglitazone/metformin fixed-dose combination therapy compared with monotherapy with either rosiglitazone or metformin in patients with uncontrolled type 2 diabetes. Diabetes Obes Metab 2006;8:650-60.

111. Perez A, Zhao Z, Jacks R, Spanheimer R. Efficacy and safety of pioglitazone/metformin fixed-dose combination therapy compared with pioglitazone and metformin monotherapy in treating patients with T2DM. Curr Med Res Opin 2009;25: 2915-23.

112. Inzucchi SE, Viscoli CM, Young LH, Furie KL, Gorman M, 
Lovejoy AM, Dagogo-Jack S, Ismail-Beigi F, Korytkowski MT, Pratley RE, Schwartz GG, Kernan WN; IRIS Trial Investigators. Pioglitazone prevents diabetes in patients with insulin resistance and cerebrovascular disease. Diabetes Care 2016;39: 1684-92.

113. Rosenstock J, Inzucchi SE, Seufert J, Fleck PR, Wilson CA, Mekki Q. Initial combination therapy with alogliptin and pioglitazone in drug-naïve patients with type 2 diabetes. Diabetes Care 2010;33:2406-8.

114. Yoon KH, Steinberg H, Teng R, Golm GT, Lee M, O’Neill EA, Kaufman KD, Goldstein BJ. Efficacy and safety of initial combination therapy with sitagliptin and pioglitazone in patients with type 2 diabetes: a 54-week study. Diabetes Obes Metab 2012;14:745-52.

115. Zelniker TA, Wiviott SD, Raz I, Im K, Goodrich EL, Bonaca MP, Mosenzon O, Kato ET, Cahn A, Furtado RHM, Bhatt DL, Leiter LA, McGuire DK, Wilding JPH, Sabatine MS. SGLT2 inhibitors for primary and secondary prevention of cardiovascular and renal outcomes in type 2 diabetes: a systematic review and meta-analysis of cardiovascular outcome trials. Lancet 2019;393:31-9.

116. Rosenstock J, Ferrannini E. Euglycemic diabetic ketoacidosis: a predictable, detectable, and preventable safety concern with SGLT2 inhibitors. Diabetes Care 2015;38:1638-42.

117. Liu J, Li L, Li S, Jia P, Deng K, Chen W, Sun X. Effects of SGLT2 inhibitors on UTIs and genital infections in type 2 diabetes mellitus: a systematic review and meta-analysis. Sci Rep 2017; 7:2824.

118. Avogaro A, Delgado E, Lingvay I. When metformin is not enough: pros and cons of SGLT2 and DPP-4 inhibitors as a second line therapy. Diabetes Metab Res Rev 2018;34:e2981.

119. Thomas MC, Cherney DZI. The actions of SGLT2 inhibitors on metabolism, renal function and blood pressure. Diabetolo- gia 2018;61:2098-107.

120. DeFronzo RA, Lewin A, Patel S, Liu D, Kaste R, Woerle HJ, Broedl UC. Combination of empagliflozin and linagliptin as second-line therapy in subjects with type 2 diabetes inadequately controlled on metformin. Diabetes Care 2015;38:38493.

121. Lewin A, DeFronzo RA, Patel S, Liu D, Kaste R, Woerle HJ, Broedl UC. Initial combination of empagliflozin and linagliptin in subjects with type 2 diabetes. Diabetes Care 2015; 38:394-402.

122. Molugulu N, Yee LS, Ye YT, Khee TC, Nie LZ, Yee NJ, Yee TK, Liang TC, Kesharwani P. Systematic review of metformin monotherapy and dual therapy with sodium glucose co-transporter 2 inhibitor (SGLT-2) in treatment of type 2 diabetes mellitus. Diabetes Res Clin Pract 2017;132:157-68.

123. Chan J, Vencio S, Proot P, Paldanius P, Mohan V. OP-0279 Screening values of glycated haemoglobin suggest regional barriers in detecting T2DM early: analysis of the VERIFY study. IDF World Diabetes Congress; 2019 Dec 2-6; Busan, Korea. Available from: https://conference.idf.org/cmPortal/Searchable/BU2019/config/normal\#!abstractdetails/0000180380.

124. Griffin SJ, Leaver JK, Irving GJ. Impact of metformin on cardiovascular disease: a meta-analysis of randomised trials among people with type 2 diabetes. Diabetologia 2017;60: 1620-9.

125. Agency for Healthcare Research and Quality (AHRQ): Quality and patient safety resources. Available from: http://www. ahrq.gov/professionals/quality-patient-safety/index.html (cited 2020 Aug 19).

126. Khazrai YM, Buzzetti R, Del Prato S, Cahn A, Raz I, Pozzilli P. The addition of $\mathrm{E}$ (Empowerment and Economics) to the $\mathrm{ABCD}$ algorithm in diabetes care. J Diabetes Complications 2015;29:599-606. 